\title{
Financial and economic analyses of the impact of cattle mastitis on the profitability of Egyptian dairy farms
}

\author{
M. F. Azooz ${ }^{1}$ D, Safaa A. El-Wakeel ${ }^{2}$ and H. M. Yousef ${ }^{3}$ \\ 1. Central Laboratory for Evaluation of Veterinary Biologics, Abbasia, Cairo, Egypt; 2. Animal Reproduction Research \\ Institute, 5 Garden Center Research Street Haram, Giza, Egypt; 3. Department of Infectious Diseases, Faculty of \\ Veterinary Medicine, Cairo University, Giza, Egypt. \\ Corresponding author: M. F. Azooz, e-mail: mohamed.azzoz.74@gmail.com \\ Co-authors: SAE: affalwakeela@gmail.com, HMY: hmyoussef49@gmail.com \\ Received: 03-05-2020, Accepted: 21-07-2020, Published online: 02-09-2020
}

doi: www.doi.org/10.14202/vetworld.2020.1750-1759 How to cite this article: Azooz MF, El-Wakeel SA, Yousef HM (2020) Financial and economic analyses of the impact of cattle mastitis on the profitability of Egyptian dairy farms, Veterinary World, 13(9): 1750-1759.

\begin{abstract}
Aim: This study aimed to evaluate and quantify the different factors affecting the costs of mastitis in cattle, to quantify the annual and monthly financial losses attributed to mastitis, and to estimate production losses using average linear scores found on The Dairy Herd Improvement Association somatic cell count (SCC) sheets and bulk tank SCC per lactation number.
\end{abstract}

Materials and Methods: All data (bovine mastitis-associated costs and expenditures in Egyptian dairy herds) were analyzed using SPSS/PCT, 2001. A partial budget technique using spreadsheet software and the general linear model procedure was used to analyze the productive and financial measures.

Results: Mastitis was present in $57.1 \%$ of cows (240/420), while clinical mastitis (CM) was present in $19 \%$ of them (80/420). The geometric mean of SCC/ml in bulk tank milk samples of 150 cattle dairy farms was $556.3 \times 10^{3}$. The annual subclinical mastitis (SCM)-related economic loss was 21,933,258.6 LE, and the two most important cost components were the subsequent decrease in milk production and quality premium losses (93\% and 7\% of SCM costs, respectively). The quality premium loss was $1,369,602.1 \mathrm{LE}$. On the other hand, the annual economic loss due to decreased milk production as a result of SCM was 20,563,656.5 LE. The total cost of $80 \mathrm{CM}$ cases, including the failure and preventive costs, was 1,196,871.4 LE, including 1,169,150.4 LE failure costs (106,336.0 LE in direct costs and 1,062,814.4 LE in indirect costs) and 27,721.0 LE preventive costs. The average cost per CM case was 28,760.9 LE, including veterinary time and consultation fees of 250.0 LE (1\%), labor 562.5 LE (2\%), premature culling 736,000.0 LE (77\%), decreased milk production 4085.18 LE (13.7\%), discarded milk 185.3 LE (1\%), and drugs and treatments 328.9 LE (1\%). The total costs of CM (expenditures) extra control and preventive measures, including the diagnosis of CM for 80 cows annually in 20 Egyptian dairy farms were 27,721.0 LE, representing 346.5 LE or 1\% of the total cost of CM cases. The cost of monitoring and diagnostic measures was 8635.2 LE, representing 107.9 LE or $1 \%$ of the total cost of a case of CM.

Conclusion: The method used for cost estimation, in this study, is highly adaptable to individual cattle farms and had a major role in assessing specific control and management measures. The concepts described in this paper help to improve our understanding of the full economic impact of clinical and subclinical mastitis in cattle in Egypt. Assessing the economic losses from mastitis to determine the economic costs and losses occurring in Egyptian dairy farms is critical for encouraging farmers to acknowledge the scale of the problem and implement effective management practices aimed at improving mastitis control and reducing the associated costs.

Keywords: clinical mastitis, economic impact, financial losses, subclinical mastitis.

\section{Introduction}

Bovine mastitis is regarded as one of the most economically damaging diseases in the dairy industry globally [1-3]. There is a need for accurate information about the actual costs of mastitis to establish appropriate economic incentives to prevent and treat it. Such information would help to evaluate the viability of preventive measures concerning a single dairy

Copyright: Azooz, et al. Open Access. This article is distributed under the terms of the Creative Commons Attribution 4.0 International License (http://creativecommons.org/licenses/by/4.0/), which permits unrestricted use, distribution, and reproduction in any medium, provided you give appropriate credit to the original author(s) and the source, provide a link to the Creative Commons license, and indicate if changes were made. The Creative Commons Public Domain Dedication waiver (http://creativecommons.org/ publicdomain/zero/1.0/) applies to the data made available in this article, unless otherwise stated. cow, a whole herd, as well as the whole dairy sector. The costs of bovine mastitis can be illustrated and divided into two main categories: Production losses and control-related expenditures [4]. Economic losses due to mastitis can be defined as a reduction of output due to this disease and an absence of benefits that would otherwise be accrued in the absence of mastitis. The former of these can be exemplified by milk that has to be discarded following treatment with antibiotics, while the latter could refer to milk that is never produced as a result of this disease. Expenditures are additional inputs needed to reduce losses due to mastitis, either by reducing the impact of mastitis, such as treating mastitis-affected cows or by preventing mastitis losses from occurring, as in the case of investments in preventive measures. Mastitis costs are also 
classified into two main categories: Those occurring directly and indirectly [5]. Direct costs consist of veterinary services, diagnostics, treatments, additional labor requirements, and discarded milk (during the course of treatment). Indirect costs are defined as those that are not always obvious to the milk producer, also known as hidden costs. Indirect losses due to subclinical mastitis (SCM) are not well recognized by many farmers, but include reduced milk yield, premature culling losses, and reduced quality premiums [6]. It is generally accepted that SCM accounts for the majority of the economic costs of mastitis. Education on this matter is critical because unrecognized indirect losses would be a reason for the difficulty in implementing mastitis control measures. Mastitis can involve two main forms: Clinical and subclinical forms. From an economic perspective, for many cattle farms, SCM is thought to be the most economically important type of mastitis because of the long-term effect of chronic infections on total milk yield. It causes substantial damage to the milk secretory cells and results in reduced milk production, changes in milk composition and quality, and also a shortened lifespan of diseased animals [7].

SCM has been shown to be responsible for most of the economic losses due to mastitis, with a reduction in milk production being the main factor. It has been reported [8] that the economic losses caused by SCM in the United States dairy industry exceed \$1 billion annually. Typically, SCM costs£140 (\$226) per case; the decrease in milk production, preventive and control measures, and premature culling costs was the top three cost categories. Within high bulk tank somatic cell count (BTSCC) herds, the cost of SCM was £217 (\$351) per case; within low-BTSCC herds, the typical cost of SCM was $£ 68.90$ (\$111.40) per case [9]. Several studies have taken all of the direct and indirect costs of clinical mastitis (CM) into consideration and produced average figures of $\$ 179$ [10], \$254 [11], \$266 [12], \$444 [13], and \$518 [14] for the cost of a case of CM. Quantification and measurement of the economic losses of cattle clinical and subclinical mastitis are mainly based on two approaches: Analysis based on farm livestock productivity data and data analysis through partial budgeting and dynamic simulation. The economic losses due to mastitis can be estimated and assessed by various methods. Partial budgets are generally easy to design and play an important role in providing an accurate estimate of the economic impact of mastitis in the dairy sector; they can be used by advisors and farmers to support decisions concerning animal health management $[5,6,15,16]$.

Against this background, the main objectives of this study are to quantify and assess the annual herd economic losses caused by bovine clinical and subclinical mastitis within large Egyptian dairy herds. These objectives are often achieved using the following approaches: Quantification, determination, and evaluation of the incidence and prevalence of clinical and subclinical mastitis in the populace, which is essential for estimating its actual cost to the dairy industry. In addition, identification of the preventive and therapeutic measures undertaken is required. It is usually easy to calculate the expenditure on mastitis control, through collection and analysis of various sources of data, substances and records, the scientific literature, regulations, reviews, reports, suggestions, and recommendations, as well as websites and the internet. Evaluation and quantification of the different factors affecting CM costs are also important, including estimation and evaluation of selected factors associated with current expenditures for mastitis treatment and control and mastitis-associated output losses, including factors related to drugs, discarded milk, veterinary services, labor, product quality, diagnostics, reduced milk yield, and culling. Moreover, there is a need for quantifying annual and monthly financial losses attributable to SCM and estimating production losses using average linear scores found on The Dairy Herd Improvement Association (DHIA) SCC sheets and BTSCC per lactation number.

\section{Materials and Methods}

\section{Ethical approval}

The approval from the Institutional Animal Ethics Committee to conduct this study was not required as no invasive procedure on the animals was performed. However, this study was conducted in accordance with the standards of Institutional Animal regulations and Ethics of Animal Reproduction Research Institute, Haram, Giza, Agricultural Research Center.

\section{Animals, study design, and study area}

A cross-sectional study was conducted from 2017 to 2019 on field data collected during field Ph.D. study entitled "Epidemiological studies on bovine mastitis in Egypt in Delta Region, Alexandria Road and the upper and lower Egypt Districts." Samples were collected from a total number of 170 private, dairy cattle farms with total population number 9810, lactating cows belonging to Cairo, Giza, Qalubia, Sharkia, Monofia, Alexandria, Behera, Dakahlia, Bensulf, Fayoum, Sohag, and Aswan and Asuit governorates.

The study animals were dairy cattle originating from intensive dairy herds. The intensive dairy farms contained cattle from small, medium, and large dairy herds. The farms were selected based on the availability of lactating cows within the farm and the owners' willingness to participate. Economic data were obtained from relevant records stored at those farms. Cow parity was defined as follows: Primiparous (first-lactation) and multiparous (second lactation or later). Cows were machine-milked 3 times a day in milking parlors. Teats of cows were sanitized by dipping them in a $0.5 \%$ iodine teat dip before and after milking. The age of the cows was between 2.5 and 6 years in different stages of lactations. A total of 420 composite milk samples and 1680 quarter milk 
samples were collected from 420 lactating animals at 20 cattle dairy farms, having 1178 dairy cows, among which 80 showed clinical signs of mastitis. Overall, 150 bulk tank milk samples were collected from 150 cattle dairy farms, derived from a total of 8667 dairy cows. The udder was examined clinically in accordance with methods described previously [17], and 340 apparently healthy lactating animals were examined for indirect estimation of the SCC using the California Mastitis Test, in accordance with previously described methods [18-20]. The individual composite milk samples and bulk tank milk samples were automatically examined for SCC using Bently soma count 150 (Bently, USA), in accordance with previously described methods [21].

\section{Questionnaire survey and data collection tools for the economic model}

All variables needed for the economic model were determined in line with previously described methods [7]. The main information collection tools used to acquire records on bovine mastitis-associated costs and expenditures in Egyptian dairy herds were a questionnaire and personal interviews with farm owners conducted in accordance with a previously described design [11,22]. The questionnaires and supporting material were established based on data from the literature and expert estimates. The questionnaire was designed mainly with questions on three categories. The first focused on general farm characteristics and also the status of mastitis. The second part addressing the bonus/penalty system was tabulated into two main parts: The first one dealing with the bonus system and the other one concerning the penalty system. The farm owners were asked about some aspects, statements, and declarations concerning the bonus and penalty systems. Farm owners were then asked about how large the bonus or penalty (depending on the questionnaire version) for various BTSCC thresholds $(400,000,350,000,300,000,250,000$, and 200,000 cell $/ \mathrm{ml}$ ) would have to be for them to alter their farm management so as to remain below that threshold. The third category concerned the implementation of current mastitis management measures (milkers wearing gloves, teat dipping preparations, milking cows in groups based on SCC, dry cow therapy, culling policy, and diagnostics).

\section{Economic framework for the current study}

The mastitis economic framework was carried out in accordance with previously described methods [7,23-26]. A cross-sectional study was designed to collect data on factors previously identified in studies to have an impact on mastitis-associated costs. Selected factors were those dealing with current expenditures for mastitis treatment and control and mastitis-associated output losses, and included factors related to drugs, discarded milk, reduced milk yield, veterinary services, labor, product quality, diagnostic, culling, materials, and investments. For each mastitis cost component, equations were formulated to estimate the cost over a year for a given herd.

\section{Quantification of veterinary services, time, and con- sultation fees}

Veterinary services, time, and consultation fees were quantified in accordance with previously described methods $[7,24,26]$. These were quantified by determining the number and proportion of $\mathrm{CM}$ cases attended by a veterinarian, average cost per veterinary visit, and costs and fees of professional advice concerning herd mastitis-related issues.

\section{Estimation of drug and treatment costs}

Assessment of drug and treatment costs was carried out in accordance with the methods described previously $[24,26,27]$. To measure the economic costs of drugs used for CM treatment, we took into consideration for every farm the number of CM cases over a year, the proportion of severe cases, the proportion of mild and moderate $\mathrm{CM}$ cases that were treated, the average number of cases per day treated, the frequency of therapeutic administrations per day, and the cost of therapeutics per administration.

\section{Economic losses due to discarded milk}

The economic losses from discarded milk were calculated in accordance with the methods described previously $[15,23,24,26]$. The cost of discarded milk can be assessed from the calculation of the number of CM cases, average duration of treatment, the proportion of $\mathrm{CM}$ cases that received treatment, withdrawal time of the used drugs, duration of discarding milk in CM cases that are not treated, average daily milk production of a cow, costs of production of $1 \mathrm{~kg}$ of milk, and the proportion of discarded milk fed to calves. While the cost of milk replacement reflects the value of discarded milk that is used to displace purchased milk replacement, this value reached $85 \%$ of its cost, in accordance with methods described previously [13]. Based on this approach, discarded milk used to feed calves was assumed to have a value of $5.98 / \mathrm{kg}$ of liquid milk. Thus, the economic loss of a kilogram of discarded milk was equal to 7.04-5.98 LE, or 1.06 LE of lost potential value.

\section{Extra labor costs for mastitis}

Labor costs were quantified in accordance with the methods described previously $[4,7,23,24,26]$. To calculate and measure the losses and costs of labor associated with mastitis treatment, the number of $\mathrm{CM}$ cases, mean time spent working on a CM case, and mean hourly fees were taken into account.

\section{Decrease in milk production}

Milk production yield losses were quantified in accordance with the methods described previously [23]. Subclinical milk production losses were assessed using the input of the farms' BTSCC, in accordance with methods described previously [23], and total production losses due to CM were calculated in accordance with other previously described 
methods $[11,26]$ by multiplying the number of $\mathrm{CM}$ cases by the associated production losses per month.

\section{Quantification of quality premium loss and penalties}

Quality premium loss and penalties were quantified in accordance with the methods described previously $[15,23,26]$. All economic costs dealing with premium loss and penalties at the farm level are easily calculated from statements of the maximum available SCC premium, currently received SCC premium, the potential premium difference, and finally the number of hundredweights shipped in the previous month multiplied by the potential premium difference to obtain the current monthly premium opportunity.

\section{Quantification of premature culling costs}

Premature culling costs were calculated in accordance with previously described methods [15,24,26,28]. These can be quantified by estimating the number of primiparious and older cows that were culled or died due to $\mathrm{CM}$ or SCM, the costs of rearing or buying a between primiparous and multiparous cows, the money received for meat or milk when selling a cow, and the money spent on carcass disposal for dead cows.

\section{The costs of diagnostic and monitoring measures}

The costs of diagnostic and monitoring measures could be calculated in accordance with previously described methods $[24,26]$. This involved quantifying the number of samples collected in a year for CM and the costs per sample.

\section{The costs of mastitis control programs}

The costs of control measures were quantified in accordance with previously described methods $[24,26,27]$. The costs of mastitis control include expenditures that can be calculated directly from expenses for pre- and post-milking teat disinfection, use of gloves for milking and dry cow therapy, other measures such as milking machine maintenance and use of towels, or calculated in accordance with standard treatment and prevention costs and from the amount of labor for monitoring and implementing treatment, prevention, and other expenditures.

\section{Statistical analysis}

All data (bovine mastitis-associated costs and expenditures in Egyptian dairy herds) were analyzed using SPSS/PCT, 2001, in accordance with previously described methods [29]. A partial budget technique using spreadsheet software and the general linear model procedure was used to analyze the productive and financial measures.

\section{Results}

Clinical and subclinical CM was found in 57.1\% of cows (240/420). CM was found in $19 \%$ of cows $(80 / 420)$. The geometric mean of SCCs $/ \mathrm{ml}$ in BTM samples of 150 cattle dairy farms was $565.3 \times 10^{3}$.

Analyzing the economic losses due to SCM revealed that the annual SCM economic loss was first-lactation cow, the difference in milk production

21,933,258.60 LE (Table-1). It also showed that the two most important cost components were the subsequent decrease in milk production and quality premium losses $(93 \%$ and $7 \%$ of SCM costs, respectively). Assessing the quality premium loss for 150 cattle dairy herds with a total of 8867 cows gave a value of 1,369,602.12 LE. The annual economic loss due to decreased milk production as a result of SCM was 20,563,656.5 LE.

The quantification of the economic losses due to $\mathrm{CM}$ for $80 \mathrm{CM}$ cases from 20 dairy cattle farms revealed that the total cost of these cases, including the failure and preventive costs, was 1,196,871.4 LE, including 1,169,150.4 LE for failure costs $(106,336$ LE for direct costs and 1,062,814.4 LE for indirect costs) and 27,721 LE for preventive costs.

The quantification of the veterinary time and consultation fees for $\mathrm{CM}$ revealed that the mean cost of veterinary time and consultation fees was $250 \mathrm{LE}$ per case. The cost of veterinary time and consultation fees represented $1 \%$ of the total costs per CM case. The mean cost of labor was 562.5 LE per CM case (Tables-1 and 2). Labor cost represented $2 \%$ of the total costs per case.

The quantification of premature culling costs due to $\mathrm{CM}$ was also performed. The cost of premature culling due to $\mathrm{CM}$ was $736,000 \mathrm{LE}$ for $80 \mathrm{CM}$ cows per year, as shown in Table-1. The total culling in 20 cattle dairy farms with 1178 cows was 34 cows $(2.88 \%)$. Future culling and replacement loss represented $23,000 \mathrm{LE}$, constituting $77 \%$ of the total cost of a case of CM.

The total economic loss due to decreased milk production as a result of $\mathrm{CM}$ for $80 \mathrm{CM}$ cases was 326,814 LE. Decreased milk production as a result of CM represented 4085.18 LE of the total cost of a CM case.

The total cost of CM (expenditures) extra control and preventive measures, including the diagnosis of CM for 80 cows annually in 20 Egyptian dairy farms, was 27,721 LE, as shown in Table-1. (Expenditures) extra control and preventive measures represented 346.5 LE per clinical case or $1 \%$ of the total cost.

The mean drug and treatment cost of $80 \mathrm{CM}$ cases were 328.85 LE per case, as shown in Tables-1 and 2.

Table-1: The overall economic losses of cattle mastitis and supply chain management.

\begin{tabular}{llc}
\hline $\begin{array}{l}\text { Mastitis } \\
\text { losses }\end{array}$ & Parameter & Cost/LE/Year \\
\hline Subclinical & Milk yield losses & $20,563,656.4826$ \\
mastitis & Quality premium & $1,369,602.12$ \\
losses & & \\
Clinical & Medicine costs & 45,000 \\
mastitis & Preventive costs & 27,721 \\
losses & Cost of discarded milk & 100,172 \\
& Veterinary services cost & 20,000 \\
& Extra Labor cost & 45,000 \\
& Control measures costs & 27,721 \\
& Cost of premature culling & 736,000 \\
& Milk yield losses & 326,814 \\
\hline
\end{tabular}


Table-2: Estimated partial cost per case of cattle mastitis on several Egyptian dairy farms.

\begin{tabular}{|c|c|c|c|c|c|c|c|c|c|}
\hline Farm & $\begin{array}{l}\text { Average } \\
\text { medicine } \\
\text { costs/LE }\end{array}$ & $\begin{array}{c}\text { Average } \\
\text { No., days for } \\
\text { discarded } \\
\text { milk }\end{array}$ & $\begin{array}{c}\text { Average } \\
\text { production } \\
\text { for cow } \\
\text { discarded }\end{array}$ & $\begin{array}{c}\text { Milk } \\
\text { price/LE }\end{array}$ & $\begin{array}{c}\text { Total } \\
\text { cost of } \\
\text { discarded } \\
\text { milk/LE }\end{array}$ & $\begin{array}{c}\text { Labor } \\
\text { cost/ } \\
\text { case/LE }\end{array}$ & $\begin{array}{c}\text { Veterinary } \\
\text { service and } \\
\text { consultation } \\
\text { cost/case/LE }\end{array}$ & $\begin{array}{l}\text { No. of } \\
\text { clinical } \\
\text { cases }\end{array}$ & $\begin{array}{c}\text { Total } \\
\text { costs/Year }\end{array}$ \\
\hline F01 & 415 & 6 & 27 & 1.06 & 171.70 & 562.50 & 250 & 4 & 5596.80 \\
\hline F02 & 252 & 6 & 32 & 1.06 & 203.20 & 562.50 & 250 & 2 & 2536.04 \\
\hline F03 & 316 & 6 & 29 & 1.06 & 184.40 & 562.50 & 250 & 3 & 3938.80 \\
\hline F04 & 168 & 6 & 36 & 1.06 & 228.90 & 562.50 & 250 & 2 & 2418.90 \\
\hline F05 & 390 & 6 & 40 & 1.06 & 254.40 & 562.50 & 250 & 4 & 5827.60 \\
\hline F06 & 375 & 6 & 24 & 1.06 & 152.60 & 562.50 & 250 & 1 & 1340.50 \\
\hline F07 & 324 & 6 & 37 & 1.06 & 235.30 & 562.50 & 250 & 5 & 6859.10 \\
\hline F08 & 297 & 6 & 22 & 1.06 & 139.20 & 562.50 & 250 & 4 & 4994.80 \\
\hline F09 & 373 & 6 & 35 & 1.06 & 222.60 & 562.50 & 250 & 3 & 3570.30 \\
\hline $\mathrm{F} 10$ & 355 & 6 & 21 & 1.06 & 133.60 & 562.50 & 250 & 2 & 2602.10 \\
\hline F11 & 357 & 6 & 36 & 1.06 & 228.90 & 562.50 & 250 & 4 & 5593.80 \\
\hline F12 & 256 & 6 & 28 & 1.06 & 178.00 & 562.50 & 250 & 3 & 3739.70 \\
\hline F13 & 391 & 6 & 34 & 1.06 & 216.20 & 562.50 & 250 & 6 & 8518.40 \\
\hline F14 & 343 & 6 & 22 & 1.06 & 139.90 & 562.50 & 250 & 3 & 3886.30 \\
\hline F15 & 373 & 6 & 29 & 1.06 & 184.40 & 562.50 & 250 & 6 & 8219.60 \\
\hline F16 & 316 & 6 & 23 & 1.06 & 146.20 & 562.50 & 250 & 5 & 6373.90 \\
\hline F17 & 328 & 6 & 36 & 1.06 & 228.90 & 562.50 & 250 & 5 & 6847.30 \\
\hline F18 & 375 & 6 & 32 & 1.06 & 203.80 & 562.50 & 250 & 9 & 12402.20 \\
\hline F19 & 362 & 6 & 31 & 1.06 & 197.20 & 562.50 & 250 & 6 & 8229.90 \\
\hline F20 & 314 & 6 & 21 & 1.06 & 133.60 & 562.50 & 250 & 3 & 3780.00 \\
\hline
\end{tabular}

Therapeutic costs, which are often the most visible cost to producers, represented only $1 \%$ of the total costs of a case of CM. The mean discarded milk cost of CM was 185.25 LE, revealing that the discarded milk cost of CM represented only $1 \%$ of the total cost of a case of CM.

\section{Discussion}

The main goals of this study were to evaluate the economic costs of cattle CM and SCM in Egyptian dairy farms and to determine the distribution among the various cost components. Mastitis is regarded as the most common disease of dairy cows and causes great economic loss to the dairy industry [7,30,31]. The distribution of costs associated with $\mathrm{CM}$ varies from farm to farm and region to region, depending on the mastitis control strategy and environmental conditions. The distribution of costs can indicate the most appropriate way of establishing a mastitis control program. The total economic costs are not the most important figure [32].

The indirect losses of SCM do not seem to be well known and visible among many farmers. It is mostly accepted that SCM is responsible for the majority of economic losses due to mastitis [33]. The two most easily identifiable costs related to SCM are milk quality price penalties and loss of milk production.

The annual economic loss due to SCM was $21,933,258.6$ LE. The two most important cost components were the subsequent decrease in milk production and quality premium losses $(93 \%$ and $7 \%$ of SCM costs, respectively).

The results of assessing quality premium losses for 150 cattle dairy herds with a total of 8867 cows gave a value of 1,369,602.12 LE. As shown in the tables, these quality premiums are mostly based on
SCC because SCC reflects the inflammatory process and thus the changes in milk composition. Most milk purchasers select milk with low SCC and offer financial incentives to farmers for high-quality milk. In the dairy industry, all over the world, penalty and premium programs have been designed to produce incentives and motivations for dairy producers to boost milk quality [34]. Most of these programs are focused on bulk tank milk quality, for example, SCC [35]. Premium payments encourage farmers to provide high-quality milk without disrupting the milk supply chain [34]. High-SCC milk is not desirable for dairy processors because it reduces the shelf life of dairy products and reduces the quality and quantity of milk protein, thereby reducing cheese yield. All of these changes result in a less valuable product and also confer inconsistent quality on the product after a shorter period of storage. This has a great effect on the consumers' attitude to the product and thus also on their willingness to buy the product at a high price in the future. It is not the cell count by itself that is important, but the association of SCC with the changes in composition. Quality premiums are an excellent opportunity for farmers to increase the marginal profit of their farms because they provide one of the few incentives for farmers to significantly impact the value of the milk that they receive [27].

On the other hand, the annual economic loss due to decreased milk production as a result of SCM was 20,563,656.5 LE, which is close to a previously reported value of $\$ 800,000$ [36]. A decrease in milk production due to subclinical mastitis has been proven to have a great effect economically $[37,38]$. The SCM production losses are calculated based on the BTSCC. Reduced milk production is the largest indirect cost associated with mastitis, although the precise size of 
this loss varies [39-41]. The losses because of a high BTSCC can be considered invisible losses, so they are hidden costs or a lost opportunity for income [11]. The measurement of the SCC in bulk milk is the universal method of evaluating the occurrence of mastitis in dairy herds; therefore, there are significant correlations between the BTSCC of a farm and the economic losses related to decreased milk production and quality $[11,42]$.

The results of quantifying the economic losses of $\mathrm{CM}$ for $80 \mathrm{CM}$ cases from 20 dairy cattle farms revealed that the economic impact per case of $\mathrm{CM}$ could be classified into two main categories: Failure costs and preventive costs. Failure costs were, in turn, classified into two main categories: Direct and indirect costs. Direct costs include diagnostic testing, therapeutics, discarded milk, veterinary services, and labor. Indirect costs include future milk production loss and costs related to premature culling. Preventive costs are related to preventive measures in terms of equipment, consumables (diagnostics and chemicals), and the use of other resources to prevent diseases (increased labor) [43]. The total costs of $80 \mathrm{CM}$ cases, including the failure and preventive costs, resulted in a total economic cost of $1,196,871.4 \mathrm{LE}$, including 1,169,150.4 LE for failure costs $(106,336 \mathrm{LE}$ for direct costs and 1,062,814.4 LE for indirect costs) and 27,721 LE for preventive costs, as shown in Table-1. This finding does not match the value of $\$ 19,889$ [26], with an average cost per CM case of 28,760.9 LE. This result is discordant with previously reported values of \$179 [10], \$254 [11], \$266 [12], \$444 [13], €500 [44], $\$ 518$ [14], €519 [5], and €269 [45].

The mean cost of veterinary time and consultation fees of CM was $250 \mathrm{LE}$ per case. This result is discordant with previously reported values of $\$ 4$ [13] and $€ 54$ [46]. The costs of veterinary time and consultation fees represent $1 \%$ of the total costs per clinical mastitis case, which agrees with a previous study [13], in which the cost of veterinary services was asserted to represent a small amount of the cost of each clinical mastitis case, but fails to match another reported value of $14 \%$ [46].

The mean cost of labor related to CM was 562.5 LE per CM case, which matches previously reported values of $€ 24$ [46] and \$21 [13], but is discordant with another study [27], in which the labor cost per CM case was estimated at $€ 82$. Labor cost represents $2 \%$ of the total costs per case, which generally accords with the previous findings of 3\% [26], 7\% [46], and $4 \%$ [13]. In many countries, besides delivering drugs, the veterinarian might have to spend time on diagnosis of a CM case, so it is very difficult to estimate the cost of labor [47]. The cost of labor also varies from one farm to another. The problem with quantifying labor is in determining the hourly price; the workers' time should also be included in the calculations of the cost of mastitis. The assessed time spent per CM case varies and depends on various factors such as the type of mastitis, milk yield, farm size, hired labor, and farm owner. For example, acute cases of mastitis, characterized by general illness, require more time for treating, nursing, and frequent stripping than mild subacute mastitis, which is associated only with changes in the milk [24].

Indirect CM costs such as premature culling costs are complicated to determine [7]. The cost of premature culling due to $\mathrm{CM}$ was $736,000 \mathrm{LE}$ for $80 \mathrm{CM}$ cows per year. The total number of cullings at 20 cattle dairy farms with 1178 cows was 34 cows $(2.88 \%)$. Our findings agree with corresponding previous values of $15 \%$ [27] and 20\% [11], while being discordant with others of $16 \%$ [48] and 9\% [49]. Culling is the result of a decision by the dairy farmer. Future culling and replacement loss represents $23,000 \mathrm{LE}$ or $77 \%$ of the total cost of a case of CM. Our results agree with the previous studies [7,24,50,51], in which it was mentioned that cows with mastitis have a higher risk of being culled and, therefore, the premature culling cost is considered one of the most important components of the economic costs of mastitis CM is one of the foremost important reasons for culling. Our results fail to match previous findings of $€ 72$ (20\%) [46] and $39.4 \%$ [51], and a previous study [13], in which it was reported that future culling and replacement loss represents $\$ 182$ or $41 \%$ of the total cost of a case of CM, or $48 \%$ [26] of this cost. It is vital to understand the culling process in dairy herds and its consequences so as to optimize dairy production [52]. Involuntary culling can be defined as when a cow leaves the herd for reasons that do not seem to be of the farmer's choice. Udder health is considered one of the foremost reported reasons for culling in dairy herds [53]. Culling behavior by producers is additionally highly dependent on and determined by farms' specific management factors (stocking density, disease incidence, disease detection, and treatment success) and also on the economic climate at the time (feed costs, availability and cost of replacements, and cow prices on the market) [54]. Cows that do not respond favorably to treatment can have repeated flare-ups of $\mathrm{CM}$ and should be culled, as their continued presence within the herd may result in other cows becoming infected. The cost related to involuntary culling because of $\mathrm{CM}$ is taken into account among the most important parameters and constituents of the total cost of $\mathrm{CM}$ and is known as a hidden cost that is not obvious to dairy farmers [6]. Further economic losses will be expected as the milk yield of primiparous cows is lower than that of multiparous cows, and since that yield of a heifer is also disappointing [7]. Culling cost is very complicated to determine. We calculated the difference between the price of a dairy cow for milk production and the price of a cow when culled for meat at a slaughterhouse. This reached about 23,000 LE, which matches a previous finding of $€ 1051$ [55], so the decision to cull a cow with mastitis can be seen as a loss, but may be seen as a preventive measure 
against persistent, recurrent mastitis to prevent new cases of mastitis within the herd, providing an additional benefit in agreement with a previous study [11]. Culling might play a very important role in reducing the overall herd-level prevalence of CM [6]. Culling of cows with chronic mastitis is commonly considered an effective method for controlling mastitis [56].

The total economic loss due to decreased milk production as a result of $\mathrm{CM}$ for $80 \mathrm{CM}$ cases was $326,814 \mathrm{LE}$, which does not match a previous finding of $\$ 6,703$ [26]. Decreased milk production as a result of CM represents $4085.18 \mathrm{LE}$ of the total cost of a CM case. Our results match a previous value of $€ 132$ [46] but not values of $€ 64$ [57] and \$115 [10]. The total economic losses due to decreased milk production as a result of $\mathrm{CM}$ represent $13.7 \%$ of the total cost of clinical mastitis cases; this result almost matches a previous finding of $18.2 \%$ [58] but is largely discordant with values of $25.5 \%$ [57], 28\% [13], 34\% [26], $64 \%$ [10], and $62.18 \%$ [59]. Out of the total of $80 \mathrm{CM}$ cases from 20 Egyptian dairy farms, 27 animals at first parity showed a decrease in milk production $(17 \%)$, while 53 animals at second parity or later showed a $22 \%$ decrease in milk production. These results fail to match those of a previous study [60], in which it was mentioned that the milk loss in the $1^{\text {st }}$ month after CM was assumed to be reduced by $40 \%$ in primiparous and $50 \%$ in multiparous cattle. The second parity multiparous cows are at a higher risk of developing CM (277,541.71 LE) and suffer more severe milk yield loss than primiparous cows $(49,272.96 \mathrm{LE})$, which agrees with the previous findings [61]. The economic losses due to decreased milk production related to $\mathrm{CM}$ are regarded as one of the most important components of the cost of CM [11].

The total cost of CM (expenditures) extra control and preventive measures, including the diagnosis of CM per 80 cows annually in 20 Egyptian dairy farms, was 27,721 LE, which was lower than the milk yield economic costs. (Expenditures) extra control and preventive measures represented 346.5 LE per clinical case, which generally matches a previous finding of $€ 15$ [46]. (Expenditures) extra control and preventive measures represented $1 \%$ of the total cost of a case of CM. Mastitis preventive costs were composed mainly of costs related to farm management measures implemented to prevent mastitis. The preventive costs of every measure generally consisted of three main cost factors: Labor, consumables, and investments. Labor is defined as the time necessary to perform the measure. Consumables consist of measures of used goods. Investments were the depreciation and deflation costs of materials lasting longer than a year [27]. Our findings match a previous study [26], in which it was stated that the costs of mastitis preventive and control measures on Canadian dairy farms were lower than the milk yield costs, but not another study [58], in which the cost of mastitis preventive and control measures on Canadian dairy farms was estimated at $€ 120$ per cow per year, which was higher than the milk yield costs. We take into consideration the most important expenditures and control measures performed for the control of CM; these include cleaning of cubicles, pre- and post-milking teat dipping, use of gloves for milking, dry cow therapy, and maintenance of milking machines. There is also a substitution relationship between preventive costs and failure costs. The higher the preventive costs, the lower the failure costs of production diseases, and vice versa [43]. Studies on the economics of mastitis have generally dealt with failure costs. Only a few studies have assessed the economic losses of preventive measures. The costs of pre-milking teat dipping include the time the milker takes for pre-stripping, washing, and drying the udders; the use of water and teat disinfectant for washing; and the use of paper towels for drying the udders [24]. Expenditure on mastitis control is determined, by which control methods are implemented, that is, pre-milking preparation of the udders, teat disinfection, dry cow therapy, monitoring measures, and maintenance of milking machines [24]. The cost of monitoring and diagnostic measures for $80 \mathrm{CM}$ cases was 8635.2 LE, representing $107.94 \mathrm{LE}$ or $1 \%$ of the total cost of a case of CM. Our results agree with one study's finding of a corresponding value of $2 \%$ (\$10) [13] but disagree with another of \$59 [26]. The cost of detecting and characterizing mastitis-causing organisms from infected cows varies and depends on the number of samples submitted and the laboratory used for culturing. The price of materials (wipes, iodine, alcohol, and sample tubes) should be added to the calculations of the mastitis control program. The labor cost is known as an element of the mastitis cost and should also be added to the calculations.

The mean drug and treatment cost of the 80 cases of CM were 328.85 LE per case. Therapeutic costs, which are often the most visible costs to producers, represented only $1 \%$ of the total costs of a case of CM. Our results disagree with a value of $23 \%$ in one study [62] and findings in another study [13], in which the cost of treatment of clinical cases was estimated to be $\$ 36$, representing $8 \%$ of the total cost of a CM case. Treatment of cows suffering from SCM during the milking period is infrequently performed in Egypt because of concerns regarding the economic efficiency of SCM treatment during lactation and the risk of antimicrobial residues [63]. Therapeutic protocols are based mainly on the severity of clinical signs, and on many farms, not all CM cases are treated [26]. Different treatment protocols were thus known to be used for mild and moderate CM compared with severe CM [26]. When mild and moderate CM is treated, such cases are supposed to be treated only with intramammary antimicrobials. The treatment of severe CM, based mainly on systemic antimicrobials and anti-inflammatory drugs in addition to the typical intramammary treatment. The therapeutic costs of CM depend mainly on the prognosis of CM cases. Based on the 
assumption that discarded milk was fed to calves, the results in the tables revealed that the mean CM-related cost of discarded milk was 185.25 LE. The cost of discarded milk due to $\mathrm{CM}$ represented only $1 \%$ of the total costs of a case of CM. This finding nearly agrees with a value of $\$ 25(5.7 \%)$ [13] but disagrees with ones of $\$ 1445$ (11\%) [26], 60\% [10], $10 \%$ [11], $€ 60$ [46], and 73\% [62]. The amount of discarded milk is the cow's daily production at the time of onset of clinical symptoms or treatment and is usually multiplied by 6 days in terms of the milk price given to the farmer. In some farms, some discarded milk could be used as calf feed. The choice of feeding mastitic milk to calves might offer an annoyed farmer some support, but should be carefully considered.

\section{Conclusion}

This study quantified the cost of clinical and subclinical mastitis in cattle using average linear scores [found on The DHIA SCC sheets] and BTSCC per lactation number. It gives insight into current market conditions and management practices in Egypt. The prevalence of cattle mastitis (CM and SCM) in individual cows at the examined dairy farms was $57.1 \%$ (240/420). CM was found in $19 \%$ of cows (80/420). The analysis of BTM samples for SCC revealed that the geometric mean of SCCs $/ \mathrm{ml}$ in BTM samples at 150 cattle dairy farms was $565.3 \times 10^{3}$. The results of analyzing the economic losses due to SCM revealed that the annual SCM economic loss was 21,933,258.6 LE and that the two most important cost components were the subsequent decrease in milk production and quality premium losses $(93 \%$ and $7 \%$ of SCM costs, respectively). The total quality premium loss for 150 cattle dairy herds with a total of 8867 cows was 1,369,602.12 LE. On the other hand, the annual economic loss due to decreased milk production as a result of SCM was 20,563,656.5 LE. In terms of the total cost of $80 \mathrm{CM}$ cases including the failure and preventive costs, a value of 1,196,871.4 LE was obtained, including 1,169,150.4 LE failure costs $(106,336 \mathrm{LE}$ for direct costs and 1,062,814.4 LE for indirect costs) and 27,721 LE preventive costs, with an average cost per CM case of $28,760.88 \mathrm{LE}$. The mean cost of veterinary time and consultation fees represented $250 \mathrm{LE}$ (1\%) per CM case. The mean cost of labor was 562.5 LE $(2 \%)$ per CM case. The cost of premature culling due to $\mathrm{CM}$ was $736,000 \mathrm{LE}$ per $80 \mathrm{CM}$ cows per year, and the total percentage of culled animals in 20 cattle dairy farms with 1178 cows was $20.8 \%$. Future culling and replacement loss represented $23,000 \mathrm{LE}$ or $77 \%$ of the total cost of a case of CM. The total economic loss due to decreased milk production as a result of $\mathrm{CM}$ for $80 \mathrm{CM}$ cases was 326,814 LE. Decreased milk production as a result of CM was represented 4085.18 LE or $13.7 \%$ of the total cost of a clinical mastitis case. The total cost of CM (Expenditures) extra control and preventive measures, including the diagnosis of $\mathrm{CM}$ in 80 cows annually in 20 Egyptian dairy farms, was
$27,721 \mathrm{LE}$, representing $346.5 \mathrm{LE}$ or $1 \%$ of the total cost of a CM case. The cost of monitoring and diagnostic measures for $80 \mathrm{CM}$ cases was 8,635.2 LE, representing 107.94 LE or $1 \%$ of the total cost of a case of $\mathrm{CM}$. The mean drug and treatment costs of $\mathrm{CM}$ were $328.85 \mathrm{LE}$ per CM case. Therapeutic costs represented only $1 \%$ of the total costs of a case of CM. Based on the assumption that discarded milk was fed to calves; the mean discarded milk cost of CM was 185.25 LE. The cost of discarded milk of CM represented only $1 \%$ of the total cost of a case of CM. The method used for cost estimation in this study is highly adaptable to individual cattle farms and played a major role in assessing specific control and management measures. The concepts described in this study help to improve our understanding of the full economic impact of clinical and subclinical mastitis in cattle.

\section{Authors' Contributions}

MFA and HMY designed the concept of the review article, and MFA and HMY designed and performed study design and the economic framework. SAE drafted and revised the manuscript. All authors read and approved the final version.

\section{Acknowledgments}

This work was supported by the Department of Udder Health and Neonates, Animal Reproduction Institute, ARC, El-Haram, Giza, Egypt, for their support.

\section{Competing Interests}

The authors declare that they have no competing interests.

\section{Publisher's Note}

Veterinary World remains neutral with regard to jurisdictional claims in published institutional affiliation.

\section{References}

1. Skuce, P.J., Bartley, D.J., Zadoks, R.N. and Macleod, M. (2016) Livestock health and greenhouse gas emissions. In: ClimateXChange is Scotland's Centre of Expertise on Climate Change. Available from: https://www.climatexchange.org.uk/media/2031/livestock_health_and_ghg.pdf. Retrieved on 21-08-2020.

2. Getaneh, A.M., Mekonnen, S.A. and Hogeveen, H. (2017) Stochastic bio-economic modeling of mastitis in Ethiopian dairy farms. Prev. Vet. Med., 138(1): 94-103.

3. Schlesser, H. (2017) Available from: https://www.farmprogress.com/dairy/farmers-lose-110-cow-each-year-duemastitis. Retrieved on 21-08-2020.

4. McInerney, J.P., Howe, K.S. and Schepers, J.A. (1992) A framework for the economic analysis of disease in farm livestock. Prevent. Vet. Med., 13(2): 137-154.

5. Kossaibati, M.A. and Esslemont, R.J. (1997) The costs of production diseases in dairy herds in England. Vet. J., 154(1): 41-51

6. Nielsen, C. (2009) Economic Impact of Mastitis in Dairy Cows. Swedish University of Agricultural Sciences. Vol. 29. Doctoral Thesis, Swedish University of Agricultural Sciences, Acta Universitatis agriculturae Sueciae, Uppsala. p81.

7. Halasa, T., Huijps, K., Osteras, O. and Hogeveen, H. (2007) Economic effects of bovine mastitis and mastitis 
management: A review. Vet. Q., 29(1): 18-31.

8. Ott, S. (1999) Costs of Herd-level Production Losses Associated with SCM in US Dairy Cows. In: Proceedings of the $38^{\text {th }}$ Annual Meeting of National Mastitis Council, Arlington VA, Madison, WI. p152-156.

9. Yalcin, C. and Stott, A.W. (2000) Dynamic programming to investigate financial impacts of mastitis control decisions in milk production systems. J. Dairy Res., 67(4): 515-528.

10. Bar, D., Tauer, L.W., Bennett, G., Gonzalez, R.N., Hertel, J.A., Schukken, Y.H., Schulte, H.F., Welcome, F.L. and Grohn, Y.T. (2008) The cost of generic CM in dairy cows as estimated by using dynamic programming. J. Dairy Sci., 91(6): 2205-2214.

11. Huijps, K., Lam, T.J. and Hogeveen, H. (2008) Costs of mastitis: Facts and perception. J. Dairy Res., 75(1): 113-120.

12. Kossaibati, M.A. and Esslemont, R.J. (2000) The cost of CM in UK dairy herds. Cattle Pract., 8(1): 323-327.

13. Rollin, E., Dhuyvetterb, K.C. and Overton, M.W. (2015) The cost of CM in the first 30 days of lactation: An economic modeling tool. Prevent. Vet. Med., 122(3): 257-264.

14. Hagnestam-Nielsen, C. and Ostergaard, S. (2009) Economic impact of CM in a dairy herd assessed by stochastic simulation using different methods to model yield losses. Animal, 3(2): 315-328.

15. Swinkels, J.M., Rooijendijk, J.G., Zadoks, R.N. and Hogeveen, H. (2005) Use of partial budgeting to determine the economic benefits of antibiotic treatment of chronic SCM caused by Streptococcus uberis or Streptococcus dysgalactiae. J. Dairy Res., 72(1): 75-85.

16. Petzer, I.M., Etter, E.M.C., Donkin, E.F., Webb, E.C. and Karzin, J. (2017) Epidemiological and partial budget analysis for treatment of subclinical Staphylococcus aureus intramammary infections considering microbiological and cytological scenarios. Prev. Vet. Med., 148(1): 66-77.

17. Quinn, P.J., Carter, M.E., Markey, B. and Carter, G.R. (2002) Clinical Veterinary Microbiology. $4^{\text {th }}$ ed. Mosby, Edinburg, London. p287-292.

18. Schalm, O.W., Carroll, E.J. and Jain, N.C. (1971) Bovine Mastitis. $1971^{\text {st }}$ ed. Lea and Febiger, Philadelphia, USA.

19. American Public Health Association. (1992) Standard Method for the Examination of Dairy Products. 16 $6^{\text {th }}$ ed. American Public Health Association, New York.

20. Quinn, P.J., Carter, M.E., Markey, B. and Carter, G.R. (2004) Clinical Veterinary Microbiology. Wild Life Publisher, London. p95-101.

21. Zecconi, A., Casirani, G., Binda, E. and Piccinini, R. (2002) The Importance to Assess the Effects of Voluntary Milking System on Teat Tissues, Intramammary Infections and Somatic Cell Counts. Department of Animal Pathology Infectious Disease Laboratory, University of Milan, Delaval Hygiene, Technology Center, Inaugural Symposium.

22. Valeeva, N.I., Lam, T.J.G. and Hogeveen, H. (2007) Motivation of dairy farmers to improve mastitis management. J. Dairy Sci., 90(9): 4466-4477.

23. Ruegg, P.L. (2005) Production and pails of discarded milk how much money does mastitis cost you? Resources Milk Money. P 3-50: Retrieved from http://milkquality.wisc.edu/ wp-content/uploads/2011/09/how-much-money-does-mastitis-cost.pdf. Retrieved on 21-08-2020.

24. Petrovski, K., Trajcev, M. and Buneski, G. (2006) A review of the factors affecting the costs of bovine mastitis. J. S. Afr. Vet. Assoc., 77(2): 52-60.

25. Kvapilík, J. and Burdych, J. (2014) Annual Report-Cattle Rearing in the Czech Republic in 2013. ČMSCH, SCHČSS, SCHČS, ČSCHMS, Prague, CZ.

26. Aghamohammadi, M, Denis, H., David, F.K., Barkema, H.W., Henk, H., Keefe, P.G. and Simon, D. (2018) Herd-level mastitis-associated costs on Canadian dairy farms. Front. Vet. Sci., 5(14): 100.

27. Van Soest, F.J.S., Santman-Berends, I., Lam, T. and Hogeveen, H. (2016) Failure and preventive costs of mastitis on Dutch dairy farms. J. Dairy Sci., 99(10): 8365-8374.
28. Peter, E. (2020) Hoards Dairy Man. Available from: https:// www.hoards.com/article-27678-what-is-the-true-cost-ofmastitis.html. Retrieved on 21-08-2020.

29. Foster, J.J. (2001) Data Analysis Using SPSS for Windows: A Beginner's Guide. SAGE, London.

30. Hande, G., Arzu, F., Nilgün, G., Serhat, A.Y.S., Alper, C., Ece, K., Serhat, A. and Murat, F. (2015) The etiology of SCM in Jersey and Hybrid Jersey dairy cows gurler. Acta Vet. Beograd, 65(3): 358-370.

31. Rahmeto, A., Hatiya, H., Abera, M., Megersa, B. and Asmare, K. (2016) Bovine mastitis: Prevalence, risk factors and isolation of Staphylococcus aureus in dairy herds at Hawassa milk shed, South Ethiopia. BMC Vet. Res., 12(1): 270.

32. Østerås, O. (2000) The Cost of Mastitis an Opportunity to Gain More Money Roc. British Mastitis Conference, Shepton Mallet. p67-77.

33. Dahl, M.O., De Vries, A., Maunsell, F.P., Galvao, K.N., Risco, C.A. and Hernandez, J.A. (2018) Epidemiologic and economic analyses of pregnancy loss attributable to mastitis in primiparous Holstein cows. J. Dairy Sci., 101(11): 10142-10150.

34. Nightingale, C., Dhuyvetter, K., Mitchell, R. and Schukken, Y.H. (2008) Influence of variable milk quality premiums on observed milk quality. J. Dairy Sci., 91(3): 1236-1244.

35. Draaiyer, J., Dugdill, B., Bennett, A. and Mounsey, J. (2009) Milk Testing and Payment Systems Resource Book: A Practical Guide to Assist Milk Producer Groups. Food and Agriculture Organization, Rome, Italy.

36. Romero, J., Efraín, B. and Carlos, M. (2018) Assessing financial impacts of sub-clinical mastitis on Colombian dairy farms. Front. Vet. Sci., 5: 273.

37. Goncalves, J.L., Kamphuis, C., Martins, C., Barreiro, J.R. and Tomazi, T. (2018) Bovine SCM reduces milk yield and economic return. Livest. Sci., 210: 25-32.

38. Hadrich, C., Wolf, C.A., Lombard, J. and Dolak, T.M. (2018) Estimating milk yield and value losses from increased somatic cell count on US dairy farms. J. Dairy Sci., 101(1): 3588-3596.

39. Ostergaard, S. and Grohn, Y.T. (1999) Effects of diseases on test day milk yield and body weight of dairy cows from Danish research herds. J. Dairy Sci., 82(6): 1188-1201.

40. Hagnestam, C., Emanuelson, U. and Berglund, B. (2007) Yield losses associated with CM occurring in different weeks of lactation. J. Dairy Sci., 90(5): 2260-2270.

41. Gulzari, S.O., Ahmadi, B.V. and Stott, A.W. (2018) Impact of SCM on greenhouse gas emissions intensity and profitability of dairy cows in Norway. Prev. Vet. Med., 150(1) : 19-29.

42. Dillon, E.J., Hennessy, T. and Cullinan, J. (2015) Measuring the economic impact of improved control of SCM in Irish dairy herds. J. Agric. Sci., 153(4): 666-675.

43. Hultgren, J. and Svensson, C. (2009) Lifetime risk and cost of CM in dairy cows in relation to heifer rearing conditions in southwest Sweden. J. Dairy Sci., 92(7): 3274-3280.

44. Hogeveen, H. and Van der Voort, M. (2017) Assessing the economic impact of an endemic disease: The case of mastitis. Rev. Sci. Tech., 36(1): 217-226.

45. Wolter, W. and Bonsels, T. (2013) Eutererkrankungen Kosten Viel Geld. AID Infodienst Bonn. Available from: http://www.aid.de/allg/impressum.php. Retrieved on 21-08-2020.

46. Kvapilík, J., Hanuš, O., Bartoň, L., Klimešová, M.V. and Roubal, P. (2015) Mastitis of dairy cows and financial losses: An economic meta-analysis and model calculation. Bulg. J. Agric. Sci., 21(5): 1092-1105.

47. Henk, H., Steeneveld, W. and Wolf, C.A. (2019) Production diseases reduce the efficiency of dairy production: A review of the results, methods, and approaches regarding the economics of mastitis. Annu. Rev. Resour. Econ., 11(2): 289-312. 
48. Römer, A. (2012) Wie lange soll eine Kuh leben? In: Untersuchungen zur Nutzungsdauer und Lebensleistung. $22^{\text {nd }}$ Hauptversammlung des LKV Sachsen-Anhalt, Cobbelsdorf.

49. Kvapilík, J. (2014) Mastitis in dairy cows and production losses. Veterinářství, 64(7): 550-560.

50. Food and Agriculture Organization. (2014) Impact of Mastitis in Small Scale Dairy Production Systems. Food and Agriculture Organization, Rome, United Nations. p44.

51. Down, P.M., Green, M.J. and Hudson, C.D. (2013) Rate of transmission: A major determinant of the cost of CM. $J$. Dairy Sci., 96(10): 6301-6314.

52. Hadley, G.L., Wolf, C.A. and Harsh, S.B. (2006) Dairy cattle culling patterns, explanations, and implications. J. Dairy Sci., 89(6): 2286-2296.

53. Orpin, P.G. and Esslemont, R.J. (2010). Culling and wastage in dairy herds: An update on incidence and economic impact in dairy herds in the UK. Cattle Pract., 18(1): 163-172.

54. Overton, M.W. and Emmanuel, R. (2014) Mastitis in the Vital $90^{\mathrm{TM}}$ Days what's the Real Cost? High Plains Dairy Conference. p41-49.

55. Geary, U., Lopez-Villalobos, N., Begley, N., McCoy, F., O'Brien, B., O'Grady, L. and Shalloo, L. (2012) Estimating the effect of mastitis on the profitability of Irish dairy farms. J. Dairy Sci., 95(7): 3662-3673.

56. Kitschen, S. (2013) Treat or cull: What are the options for a chronic mastitis cow? Progressive Dairyman Magazine. Available from: http://www.progressivedairy.com. Retrieved on 21-08-2020.
57. Heber, I. (2013) Investitionen in die Tiergesundheit was Darf Sie Kosten? Sächsischer Milchrindtag, Groitzsch. Available from:. https://www.agrojournal.org/20/06-31.pdf Retrieved on 21-08-2020.

58. Guimarães, J.L.B., Brito, M.A.V., Lange, C.C., Silva, M.R., Ribeiro, J.B., Mendonça, L.C., Mendonça, J.F.M. and Souza, G.N. (2017) Estimate of the economic impact of mastitis: A case study in a Holstein dairy herd under tropical conditions. Prev. Vet. Med., 1(142): 46-50.

59. Sharifi, H., Mohsen, A.S., Mina, B.A. and Homayoon, B. (2014) Economic impact of mastitis in dairy cows: Case study of Tehran Province, Iran. Iran. J. Vet. Sci., 9(2): 21.

60. Houben, E.H.P., Huirne, R.B.M., Dijkhuizen, A.A. and Kristensen, A.R. (1994) Optimal replacement of mastitic cows determined by a hierarchical Markov process. $J$. Dairy Sci., 77(10): 2975-2993.

61. Steeneveld, W., Hogeveen, H., Barkema, H.W., Van den Broek, J. and Huirne, R.B.M. (2008) The influence of cow factors on the incidence of clinical mastitis in dairy cows. $J$. Dairy Sci., 91(4): 1391-1402.

62. Sadeghi-Sefidmazgi, A., Moradi-Shahrbabak, M., NejatiJavaremi, A., Miraei-Ashtiani, S.R. and Amer, P.R. (2011) Estimation of economic values and financial losses associated with $\mathrm{CM}$ and somatic cell score in Holstein dairy cattle. Animal, 5(1): 33-42.

63. Green, M., Huxley, J., Madouasse, A., Browne, W., Medley, G. and Bradley, A. (2008) Making good decisions on dry cow management to improve udder health synthesising evidence in a Bayesian framework. Cattle Pract., 16(2): 200-208. 